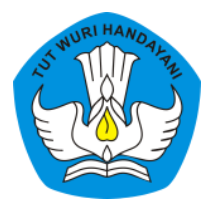

Page: 935-956

\title{
PENGEMBANGAN MEDIA WHEELSMATIK UNTUK MENINGKATKAN PEMAHAMAN KONSEP PERHITUNGAN ZAKAT DI SEKOLAH DASAR
}

\author{
Anhar \\ Sekolah Dasar Negeri 1 Jatisari, Sambi, Boyolali, Jawa Tengah, Indonesia \\ Contributor Email: anhar120884@gmail.com
}

Received: Feb 11, 2021

Accepted: Jul 1, 2021

Published: Nov 30, 2021

Article Url: https://ojsdikdas.kemdikbud.go.id/index.php/didaktika/article/view/272

\begin{abstract}
Learning Islamic Religious Education and Character and Character There is material zakat which requires students to understand mathematical concepts, because students must be able to determine the level of zakat with a nominal value of millions. Mathematical concepts must be understood easily and effectively in learning. Wheelsmatik media development is designed to improve the understanding of mathematical concepts in the material of zakat, so that there is a strengthening of mathematical concepts and an increase in student learning outcomes, especially in Jatisari 1 Elementary School, Sambi, Boyolali. This innovation was developed by applying the Rearch and Development method. The results obtained show that the percentage of student learning outcomes has increased, from before the use of Wheelsmatik media it was obtained an average of 75.38 there were still 6 students who had not completed. After using Wheelsmatic media experienced an increase in learning outcomes by an average of 83.07 and there were 3 students who had not yet completed it the first experiment, and obtained an average result of 86.15 and all students had completed the minimum completeness criteria in the second experiment. The conclusions obtained are to increase understanding of the mathematical concepts of zakat material and student learning outcomes.
\end{abstract}

Keywords: Fiqh; Zakat; Learning Outcomes. 


\begin{abstract}
Abstrak
Pembelajaran Pendidikan Agama Islam dan Budi Pekerti terdapat materi zakat yang menuntut siswa memahami konsep matematis, karena siswa harus mampu menentukan kadar zakat dengan nominal jutaan. Konsep matematis harus dipahami secara mudah dan efektif dalam pembelajaran. Pengembangan media Wheelsmatik dirancang untuk meningkatkan pemahaman konsep matematis pada materi zakat, agar terjadi penguatan konsep matematis dan peningkatan hasil belajar siswa khususnya di Sekolah Dasar Negeri 1 Jatisari, Sambi, Boyolali. Inovasi ini dikembangkan dengan menerapkan metode Research and Development. Hasil penelitian ini menunjukkan persentase hasil belajar siswa meningkat. Sebelum penggunaan media Wheelsmatik, rata-rata hasil belajar siswa 75.38 dan masih terdapat 6 siswa belum tuntas. Setelah menggunakan media Wheelsmatik rata-rata hasil belajar siswa meningkat menjadi 83.07 dan hanya 3 siswa belum tuntas pada percobaan pertama. Pada percobaaan kedua, rata-rata hasil belajar meningkat menjadi 86.15 dan semua siswa sudah tuntas. Kesimpulan penelitian ini adalah terdapat peningkatan pemahaman konsep matematis materi zakat dan hasil belajar siswa.
\end{abstract}

Kata Kunci: Fikih; Zakat; Hasil Belajar.

\title{
A. Pendahuluan
}

Pendidikan Agama Islam dan Budi Pekerti merupakan salah satu mata pelajaran yang urgent dalam membentuk akhlak siswa Indonesia, agar menjadi siswa yang beriman dan bertaqwa kepada Allah swt. Hal ini senada dengan pendapat Achmadi yang menyatakan bahwa "Pendidikan Agama Islam dan Budi Pekerti merupakan usaha untuk mengembangkan potensi untuk menjadi manusia yang bermartabat, beriman dan bertakwa kepada Allah swt., berbudi pekerti luhur (akhlak mulia), dan memiliki kemampuan untuk memikul tanggung jawab sebagai individu dan anggota masyarakat dapat terwujud"(Achmadi, 2005).

Pendidikan Agama Islam dan Budi Pekerti pada jenjang sekolah dasar, selain sebagai mata pelajaran mata pelajaran tersendiri, juga perlu diberi muatan keagamaan yang mendukung peningkatan keimanan dan ketakwaan para siswa. Pendidikan Agama Islam adalah bimbingan yang diberikan oleh seseorang kepada seseorang agar ia berkembang secara maksimal sesuai dengan ajaran Islam. Bila disingkat, Pendidikan Agama Islam adalah bimbingan terdapat seseorang agar menjadi muslim semaksimal 
mungkin (Tafsir, 1992). Pendidikan Agama Islam merupakan pondasi seseorang untuk menjadi muslim yang kaffah dengan semaksimal mungkin melaksanakan ajaran Islam.

Pendidikan Agama Islam dan Budi Pekerti meliputi Fiqih, AlQur'an, Aqidah, Akhlak, dan Tarikh yang harus dikuasai peserta didik. Pembelajaran Pendidikan Agama Islam dan Budi Pekerti sangat kompleks karena setiap aspek memiliki karakteristik tersendiri. Namun, pembelajaran Pendidikan Agama Islam dan Budi Pekerti tidak hanya memahami AlQur'an hadist semata, terdapat materi yang bersifat matematis. Materi yang bersifat matematis terdapat dalam aspek fiqih karena dalam materi fiqih terdapat materi zakat di mana peserta didik harus mampu menghitung kadar zakat seseorang.

Zakat dapat diartikan dengan harta yang dikeluarkan seseorang yang memiliki harta yang lebih untuk diberikan kepada orang yang berhak menerima dengan kadar zakat 2.5\%. Hal ini sebagaimana tertuang dalam Undang-Undang Republik Indonesia Nomor 23 tahun 2011 bahwa zakat adalah harta yang wajib dikeluarkan oleh seorang muslim atau badan usaha untuk diberikan kepada yang berhak menerimanya sesuai dengan syariat Islam.

Penentuan zakat memerlukan pemahaman konsep matematis. Hal inilah yang membuat sebagian besar siswa menganggap bahwa materi zakat sulit. Banyak siswa tidak menyukai dan tidak paham dalam menentukan zakat karena harus menghitung hingga jutaan. Hal tersebut dikarenakan dalam pembelajaran Pendidikan Agama Islam dan Budi Pekerti materi zakat disampaikan dengan metode yang tidak tepat. Selain itu dalam pembelajaran materi zakat yang harus dipahami dengan konsep matematis, guru tidak menggunakan media sehingga siswa tidak mudah memahami konsep matematis dalam zakat.

Pengamatan yang dilakukan penulis dalam pembelajaran materi zakat di Sekolah Dasar Negeri 1 Jatisari, Sambi, Boyolali belum menggunakan media yang tepat. Hasil pengamatan yang dilakukan penulis pada materi 
zakat mata pelajaran Pendidikan Agama Islam dan Budi Pekerti dijumpai hasil belajar hanya $53.84 \%$ siswa yang memenuhi Kriteria Ketuntasan Minimal (KKM). Itu menandakan bahwa masih terdapat $46.16 \%$ siswa yang belum tuntas. Salah satu upaya yang dapat mengurangi kelemahan ini adalah dengan inovasi pembelajaran, baik metode maupun media pembelajaran yang memudahkan siswa dalam pembelajaran.

Penggunaan media pembelajaran sangat penting untuk memudahkan siswa memahami materi yang dipelajari. Karena itu, guru harus memilih media yang tepat dalam sebuah proses pembelajaran. Pembelajaran Pendidikan Agama Islam dan Budi Pekerti pada materi zakat membutuhkan pemahaman konsep matematis, maka diperlukan media yang kongkrit atau media manipulatif. Bila media dimanipulasi dari berbagai bentuk termasuk benda-benda fisik, dapat digunakan sebagai media pengajaran yang melibatkan siswa dalam belajar matematika (Baggon 2010). Atas dasar itu, penulis mengembangkan media Wheelsmatik pada pembelajaran Pendidikan Agama Islam dan Budi Pekerti materi zakat yang membutuhkan pemahaman konsep matematis.

Media Wheelsmatik merupakan media yang dirancang untuk memudahkan siswa untuk menentukan zakat dalam mata pelajaran Pendidikan Agama Islam dan Budi Pekerti. Media Wheelsmatik terbuat dari kardus bekas yang ditempel 3 roda yang terbuat dari kardus ditempel gambar roda dimodifikasi angka-angka dalam roda tersebut. Roda yang ditempel dirancang agar bisa berputar dan masing-masing roda mewakili nilai jutaan, ratusan juta, dan puluhan juta.

Diharapkan penggunaan media Wheelsmatik ini dapat meningkatkan pemahaman konsep perhitungan zakat dan mampu meningkatkan hasil belajar Pendidikan Agama Islam dan Budi Pekerti pada materi zakat. Siswa juga akan mendapatkan pengetahuan dan keterampilan yang bermakna dengan Wheelsmatik, selain sebagai media pembelajaran.

Adapun penelitian pengembangan ini membahas mengenai hasil belajar siswa sebelum dan sesudah menggunakan media Wheelsmatik dan 
seberapa besar efektifitas penggunaan media Wheelsmatik dalam pembelajaran materi zakat di kelas 6 Sekolah Dasar Negeri 1 Jatisari, Sambi, Boyolali.

\section{B. Metode}

Penelitian ini menggunakan metode Research and Development $(\mathrm{RnD})$ yang merupakan model penelitian pengembangan. Penelitian pengembangan ini menggunakan model pengembangan 4D (four-D). Model penulisan dan pengembangan dengan model $4 \mathrm{D}$ terdiri dari 4 tahapan, yaitu : define, design, develop, dan dissemine (Thiagarajan, S., Semmel, S.D. \& Semmel 1974).

Tahap define/ definisi adalah kegiatan yang dilakukan untuk menetapkan dan mendefinisikan syarat-syarat pengembangan. Dalam tahap ini penulis menetapkan dan mendefinisikan pokok persyaratan yang tepat dalam penulisan ini. Setelah mendapatkan focus masalah tentang menentukan jumlah zakat yang harus dikeluarkan seseorang secara matematis. Konsep penentuan zakat ini menjadi pokok permasalahan yang harus dipecahkan yaitu minimnya media pembelajaran yang digunakan dalam masalah ini yaitu penentuan zakat.

Tahap perencanaan/ design adalah tahap kedua yang berisi kegiatan menyiapkan kerangka konseptual model dan perangkat pembelajaran (materi, media, alat evaluasi) dan mensimulasikan penggunaan model dan perangkat pembelajaran tersebut dalam lingkup kecil. Dalam tahapan ini, penulis menyiapkan konsep media pembelajaran Wheelsmatik untuk digunakan memahami materi zakat. Tahap pengembangan develop merupakan tahap ketiga yang merupakan tahap ujicoba media pembelajaran Wheelsmatik terhadap siswa Sekolah Dasar dalam materi zakat. Dalam tahap ini media pembelajaran Wheelsmatik diujicobakan dalam pembelajaran sehinga dapat diketahui seberapa efektif media tersebut dapat merubah pemahaman dan hasil belajar siswa. Tahap terakhir adalah penyebarluasan/ dissemine yaitu tahap dimana penulis melakukan penyebarluasan penggunaan media Wheelsmatik kepada teman-teman sejawat pada forum Kelompok Kerja Guru Pendidikan Agama Islam tingkat kecamatan. 
Inti media Wheelsmatik ada pada tiga lingkaran roda yang masingmasing bernilai jutaan, ratusan ribu, dan puluhan ribu. Lingkaran tersebut ditempel di kardus berbentuk persegi panjang. Setiap lingkaran roda memuat nilai yang sama, namun keterangan antar lingkaran roda berbeda sesuai nilai jutaan, ratusan ribu, dan puluhan ribu. Adapun alat dan bahan sederhana yang mudah didapat di lingkungan sekitar, antara lain (a) kardus, (b) kertas cover HVS warna, (c) kardus bekas, (d) gambar roda, (e) spidol, 6) gunting, (f) isolasi ganda, (g) lem kertas, dan (h) kawat. Alasan pemakaian bahan bekas adalah penggunaan bahan bekas dapat mengurangi sampah daur ulang sehingga membantu menjaga kelestarian lingkungan.

Proses pembuatan Wheelsmatik adalah sebagai berikut. (1) Membuat papan alas yang dibuat dari kardus bekas yang tebal dengan ukuran 50x40 cm; (2) Menyiapkan 3 gambar roda dengan masing-masing ditulis angka 25, 75, 100, 125, 150, 175, 200 dan 225; (3) Menempelkan ketiga gambar roda dengan kawat biar bisa berputar; (4) Di papan alat bagian atas kiri diberi tulisan... $\times 2.5 \%=\ldots$; (5) Bagian bawah lingkaran pertama ditulis angka 000, dibawah lingkaran kedua ditulis 00, dan lingkaran ketiga ditulis 0; (6) Pada bagian alas bawah ditulis penjumlahan hasil lingkaran pertama, kedua dan ketiga; (7) setelah selesai, media Wheelsmatik berikutnya dapat digunakan saat pembelajaran Pendidikan Agama Islam dan Budi Pekerti dan Budi Pekerti pada materi zakat di Sekolah Dasar Negeri 1 Jatisari, Sambi, Boyolali.

\section{Hasil dan Pembahasan}

\section{Hasil}

\section{a. Validasi Media Wheelsmatik}

Media Wheelsmatik merupakan media yang dikembangkan dari permainan spin atau lingkaran berhadiah yang biasa digunakan dalam kuis baik di televisi maupun kegiatan lainnya. Permainan spin umumnya berupa lingkaran yang ditulis beberapa hadiah atau berupa tantangan, seperti memutar lingkaran bila berhenti dan panah berhenti di salah satu hadiah atau berupa tantangan, maka peserta memenangkan hadiah dalam permainan 
spin tersebut. Permainan ini sangat digemari baik orang dewasa maupun anak-anak terutama anak Sekolah Dasar. Demikian juga media Wheelsmatik yang terispirasi permainan spin tersebut, namun media Wheelsmatik dipadukan dengan bentuk roda sepeda. Bentuk sepeda dijadikan icon dalam media ini karena memiliki bentuk yang unik dan anak-anak Sekolah Dasar mudah memahami. Oleh sebab itu media ini dinamakan dengan media Wheelsmatik. Media Wheelsmatik merupakan media pembelajaran yang bisa merangsang pikiran siswa agar terdorong untuk aktif dalam proses pembelajaran. Hal ini senada dengan pendapat Sukiman yang menyatakan bahwa media pembelajaran merupakan segala sesuatu yang dapat digunakan untuk menyalurkan pesan dari pengirim ke penerima sehingga merangsang pikiran, perasaan, perhatian dan minat serta kemauan peserta didik sedemikian rupa sehingga proses belajar terjadi dalam rangka mencapai tujuan pembelajaran secara efektif (Sukiman 2012).

Ide awal pengembangan media ini dari media-media pembelajaran yang digunakan dalam menentukan penambahan bilangan ratusan. Dalam media tersebut masih belum memecahkan cara menghitung zakat karena dalam menghitung seberapa zakat yang dikeluarkan seseorang sebanyak 2.5\% masih sulit dipecahkan dengan cara yang lebih mudah. Untuk itu. penulis membuat media Wheelsmatik yang berupa papan alas kardus dengan 3 lingkaran besar yang terdiri dari jutaan untuk lingkaran pertama, ratusan ribu untuk lingkaran kedua, dan puluhan ribu untuk lingkaran ketiga. Media Wheelsmatik ini untuk menghitung zakat yang dikeluarkan seseorang setiap harta yang dimiliki sebanyak $2.5 \%$.

Media Wheelsmatik dibuat untuk menentukan zakat dengan harta mulai 1 - 10 juta saja, karena untuk pembelajaran anak Sekolah Dasar kelas 6. Sedangkan untuk harta di atas 10 juta jumlah lingkaran menjadi 4 lingkaran dalam media Wheelsmatik dan untuk harta 100 juta lebih memerlukan 5 buah lingkaran, ini akan dikembangkan penulis di lain waktu. Media Wheelsmatik yang penulis buat dengan harta 1 - 10 juta ini menggunakan 3 lingkaran. Lingkaran pertama dibagi menjadi 9 bagian dengan angka 25, 50, 75, 100, 125, 150, 175, 200 dan 225, lingkaran pertama untuk menentukan 
bilangan 1-9 juta. Lingkaran kedua juga dibagi menjadi 9 bagian dengan angka 25, 50, 75, 100, 125, 150, 175, 200. dan 225, lingkaran pertama untuk menentukan bilangan 100-900 ribu. Lingkaran ketiga juga dibagi menjadi 9 bagian dengan angka 25, 50, 75, 100, 125, 150, 175, 200 dan 225, lingkaran pertama untuk menentukan bilangan 10-90 ribu. Ketiga lingkaran memiki fungsi masing-masing untuk mempermudah siswa dalam memahami perkalian jumlah harta dikali $2.5 \%$, setiap lingkaran dibuat warna yang berbeda untuk membedakan fungsi dari masing-masing lingkaran.

Media Wheelsmatik diciptakan untuk menjawab kebutuhan madia pembelajaran dalam menentukan zakat yang dikeluarkan seseorang terutama zakat mal setiap tahunnya dari harta yang dimiliki. Selama ini dalam menentukan zakat yang dikeluarkan seseorang sebanyak $2.5 \%$ masih menggunakan metode biasa dengan mengalikan jumlah harta dengan 2.5\%. Metode konvensional berupa perkalian bagi siswa Sekolah Dasar merupakan hal yang sulit apalagi jumlah harta mencapai jutaan rupiah. Masalah tersebut diharapkan dapat diselesaikan dengan mudah dengan media Wheelsmatik. Dengan memutar ketiga roda dan menjumlahkan hasil dari perkalian setiap roda maka siswa sudah dapat menentukan jumah zakat yang dikeluarkan seseorang. Adapun ilustrasi yang menggambarkan ide awal media Wheelsmatik dapat dilihat pada gambar berikut.

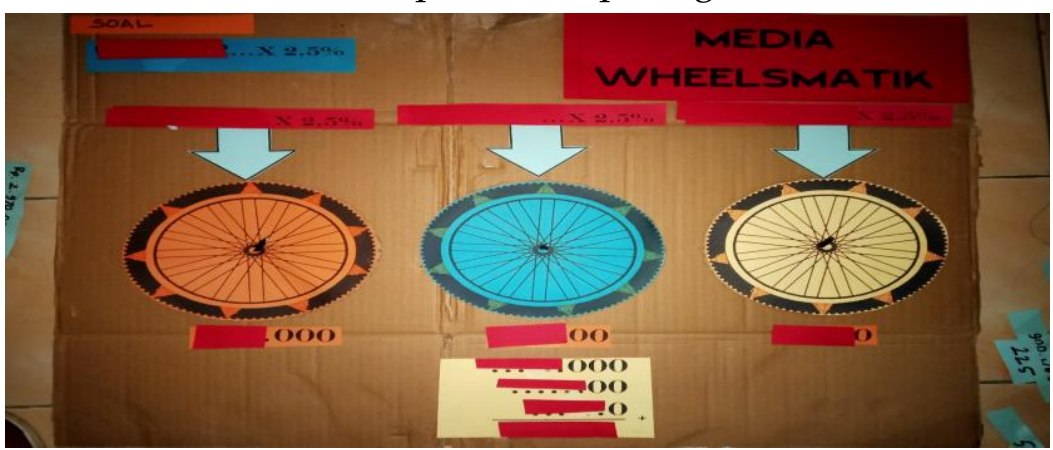

Gambar 1. Konsep ide dasar Wheelsmatik

Penemuan media Wheelsmatik didasari dari kegundahan penulis saat mengajar Pendidikan Agama Islam dan Budi Pekerti di Sekolah Dasar Negeri 1 Jatisari, dimana ditemukan banyak siswa tidak paham dan 
kesulitan dalam menghitung jumlah zakat yang harus dikeluarkan seseorang dari seluruh hartanya. Hal ini dikarenakan siswa belum mampu mengkalikan nominal jutaan dengan 2.5\%. Banyak media yang dibuat namun kebanyakan hanya memecahkan permasalahan penambahan dan perkalian angka ratusan, untuk perkalian berupa nominal uang dengan porsentasi belum ada media pembelajaran selama ini.

Media Wheelsmatik adalah sebuah media pembelajaran yang berupa papan persegi panjang berukuran 50x40 $\mathrm{cm}$ terbuat dari kardus besar, dengan lingkaran berbentuk roda dengan angka-angka di setiap roda tersebut. Fungsi rodanya adalah sebagai hasil perkalian nominal jutaan untuk roda pertama, ratusan ribu untuk roda kedua, dan puluhan ribu untuk roda ketiga. Media Wheelsmatik ini menjadi salah satu alternatif jawaban dari kegundahan penulis sebagai guru Pendidikan Agama Islam yang selama ini kesulitan menjelaskan cara menentukan zakat yang harus dikeluarkan seseorang. Dalam menentukan zakat siswa harus menghitung perkalian antara jumlah harta yang dimiliki dikali $2.5 \%$.

Media Wheelsmatik lahir setelah penulis melihat beberapa kuis spin di televisi dan beberapa media pembelajaran seperti spin tersebut namun hanya menyeleaikan konsep penambahan. Setelah melihat kuis dan media pembelajaran seperti itu, penulis mendapatkan inspirasi untuk membuat media serupa spin namun untuk menyelesaikan permasalahan perkalian nominal uang jutaan rupiah dengan porsentase. Penggunaan media Wheelsmatik digunakan dalam pembelajaran di kelas 6 Sekolah Dasar Negeri 1 Jatisari, Sambi, Boyolali. Media Wheelsmatik memudahkan siswa dalam memecahkan masalah perkalian dalam menentukan besaran zakat seseorang. Pembelajaran menggunakan media ini, guru menjadi pembimbing dan fasilitator memberikan arahan supaya siswa mudah memecahkan masalah perkalian menggunakan media Wheelsmatik. "Penggunaan media ini menjawab persoalan siswa yang cenderung kesulitan dalam menghitung zakat, karena prinsip pokok yang harus diperhatikan dalam penggunaan media adalah media itu digunakan dan diarahkan untuk mempermudah siswa belajar dalam upaya memahami kompetensi pelajaran." (Sanjaya 2008). Dengan demikian penggunaan media harus dipandang dari sudut kebutuhan siswa. 
Media pembelajaran Wheelsmatik ini diciptakan untuk menjawab kegalauan selama ini yang dirasakan guru Pendidikan Agama Islam terutama dalam memahami konsep matematis materi zakat. Perasaan sedih saat melaksanakan pembelajaran zakat di kelas 6 Sekolah Dasar Negeri 1 Jatisari karena melihat hasil belajar yang rendah. Hal ini dikarenakan belum mendapatkan media pembelajaran yang dapat mempermudah pemahaman terhadap materi zakat. Tentu kita tahu, bahwa dalam menentukan zakat diperlukan konsep matematis yang sulit bagi peserta didik memahaminya. Penulis merasakan munculnya sebuah jalan buntu pada pembelajaran zakat sehingga dibutuhkan media yang dapat memudahkan siswa memahami konsep matematis materi zakat dengan konsep yang lebih real dan mudah bagi siswa.

Saat siswa menggunakan media Wheelsmatik dalam materi zakat, siswa terbantu dalam menyelesaikan soal penentuan zakat dengan mudah. Hal tersebut merupakan salah satu pengalaman berharga yang didapat siswa terutama cara menyelesaikan nominal jutaan dikalikan $2.5 \%$. Bila soal tersebut menggunakan langkah perkalian manual, tentu membutuhkan waktu yang banyak, apalagi siswa yang berkemampuan rendah sangat kesulitan. Oleh karena itu, menggunakan media Wheelsmatik ini hanya memerlukan 3 langkah dalam menentukan zakat dengan nominal jutaan rupiah.

Media Wheelmatik ini telah dilakukan uji validitas oleh Bapak Eko Sumadi, M.Pd.I. (Dosen IAIN Kudus) dan Ibu Anisatul Barokah, M.Pd.I., M.Pd. (Dosen IAIN Surakarta).

Hasil uji validasi oleh dua orang ahli ditunjukkan dalam tabel berikut.

Tabel 1. Rekapitulasi Validasi Media

\begin{tabular}{lcc}
\hline \multirow{2}{*}{ Indikator } & \multicolumn{2}{c}{ Kesesuaian } \\
\cline { 2 - 3 } & Ya & Tidak \\
\hline Kemudahan penyediaan alat & 2 & 0 \\
\hline Kemudahan dalam merangkau alat & 2 & 0 \\
\hline Kemudahan dalam mengoperasikan alat & 2 & 0 \\
\hline
\end{tabular}

Berdasarkan tabel validasi media Wheelsmatik di atas dapat disimpulkan bahwa media Wheelsmatik valid pada semua indikator validitas media.

\section{b. Hasil Ujicoba}

Tahapan penggunaan media Wheelsmatik, sebagai berikut. (1) Guru 
menjelaskan masalah kadar zakat seseuai syariat Islam; (2) Siswa mendengarkan penjelasan guru; (3) Guru menjelaskan langkah penggunaan media pembelajaran Wheelsmatik; 4) Guru memberikan soal untuk diselesaikan menggunakan media Wheelsmatik; (5) guru membantu siswa yang kesulitan memecahkan soal dengan media Wheelsmatik.

Penerapan media Wheelsmatik pada materi zakat dapat dijelaskan sebagai berikut.

\section{1) Menentukan Jumlah Zakat yang Dikeluarkan}

Dalam menentukan jumlah zakat yang dikeluarkan pada media Wheelsmatik sangat sederhana, walaupun dalam menentukan zakat menggunakan rumus "jumlah harta x 2.5\%". Langkah menentukan jumlah zakat dengan media Wheelsmatik hanya dengan memutar masing-maisng roda, roda pertama yang memuat jutaan rupiah, roda kedua memuat ratusan ribu rupiah dan roda ketiga memuat puluhan ribu rupiah.

Contoh soal dalam percobaan 1, menentukan zakat dari Rp. 2,970,000.00.

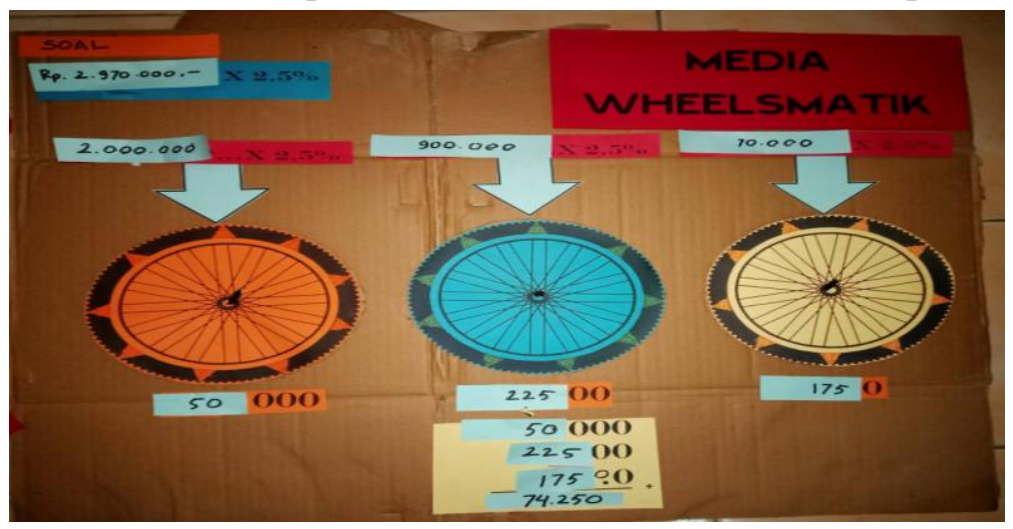

Gambar 2. Ilustrasi Penggunaan Media Wheelsmatik

Langkah penyelesaian soal percobaan pertama menentukan zakat dari Rp2.970.000.00 sebagai berikut. (1) menulis soal dibagian atas kiri media Wheelsmatik; (2) Nominal 2.970 .000 dibagi menjadi 3 bagian yaitu ditulis di atas roda pertama nominal $2.000000 \times 2.5 \%$, di atas roda kedua ditulis nominal $900,000 \times 2.5 \%$, dan di atas roda ketiga ditulis nominal $70.000 \times 2.5 \%$; (3) Hasil perkalian di roda pertama $2.000 .000 \times 2.5 \%$ maka diroda diputar pada angka 50 disesuaikan panah di atas roda pertama, hasil perkalian di roda kedua 900.000 x 2.5\% maka diroda diputar pada 
angka 225 disesuaikan panah di atas roda kedua, dan hasil perkalian $70.000 \times 2.5 \%$ maka di roda ketiga pada angka 175 disesuaikan panah di atas roda ketiga; (4) Setelah didapat angka di masing-masing roda maka hasilnya ditulis di bagian bawah roda. Roda pertama menunjukkan angka 50, maka ditulis di bawah roda ditambah 000 hasilnya 50.000, roda kedua menunjukkan angka 225, maka ditulis di bawah roda ditambah 00 hasilnya 22.500, dan roda ketiga menunjukkan angka 75, maka ditulis di bawah roda ditambah 0 hasilnya 1.750; (5) setelah mendapatkan hasil perkalian masing-masing roda, maka semua nilai dijumlahkan dibagian bawah media Wheelsmatik. hasil perkalian pada roda pertama $2.000 .000 \times 2.5 \%$ hasilnya 50,000, hasil perkalian pada roda kedua 900,000 × 2.5\% hasilnya 22,500. Hasil perkalian roda ketiga $70.000 \times 2.5 \%$ hasilnya 1,750 . hasil penjumlahan dari ketiga hasil tersebut adalah 50,000+22.500+1,750, maka hasilnya 74,250.

\section{2) Penjumlahan Jumlah Zakat}

Langkah-langkah penggunaan media Wheelsmatik dalam menentukan zakat Rp. 2.970.000.00 dikalikan 2.5\%, sebagai berikut. (1) Pada bagian bawah masing- masing roda terdapat angka yang menunjukkan jumlah ribuan. Pada roda pertama tertulis angka 000, pada roda kedua tertulis 00 dan pada roda ketiga tertulis angka 0; (2) Merinci nominal dahulu dari 2.970.000 menjadi 2.000.000, 900.000, dan 70.000; (3) Pada roda pertama $2.000 .000 \times 2.5 \%$ menunjukkan angka 50, pada roda kedua 900,000 × 2.5\% menunjukkan angka 225, dan pada roda ketiga $70.000 \times 2.5 \%$ menunjukkan angka 175; (3) Setelah ditentukan nilai pada setiap roda, maka hasil dari setiap roda tersebut dimasukan dalam isian di bawah masing-masing roda; (4) Roda pertama didapat nilai 50, maka dimasukkan dalam isian di bawah roda pertama menjadi $50+000$ hasilnya 50,000. Diartikan bahwa 2.000.000 x 2.5\% hasilnya 50.000, roda kedua didapat angka 225, maka angka tersebut dimasukkan dalam isian di bawah roda kedua, menjadi $225+00$ hasilnya 22.500 , dan roda ketiga didapat angkat 175 , maka dimasukkan dalam isian dibawah roda ketiga menjadi $175+0$ hasilnya 1,750. Proses tersebut terlihat dalam media seperti berikut. 

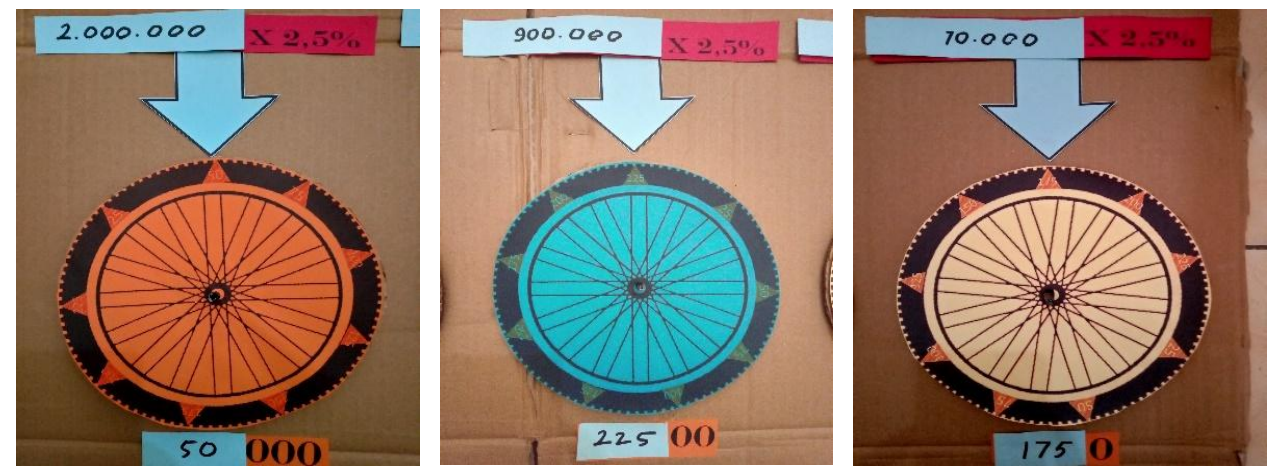

Gambar 3. Langkah perkalian dengan media Wheelsmatik

Setelah ketiga roda berhasil menunjukkan perkalian baik nominal jutaan, ratusan ribu dan puluhan ribu. Maka pada bagian bawah media Wheelsmatik terdapat penjumlahan dari hasil perkalian ketiga roda tersebut yaitu roda pertama 50.000, roda kedua 22,500 dan roda ketiga 1.750 maka hasilnya 74.250. Maka hasil zakat yang dikeluarkan dari harta Rp. 2.970.000.00 x 2.5\% adalah Rp. 74,250.00. Dapat dilihat di media Wheelsmatik sebagai berikut.

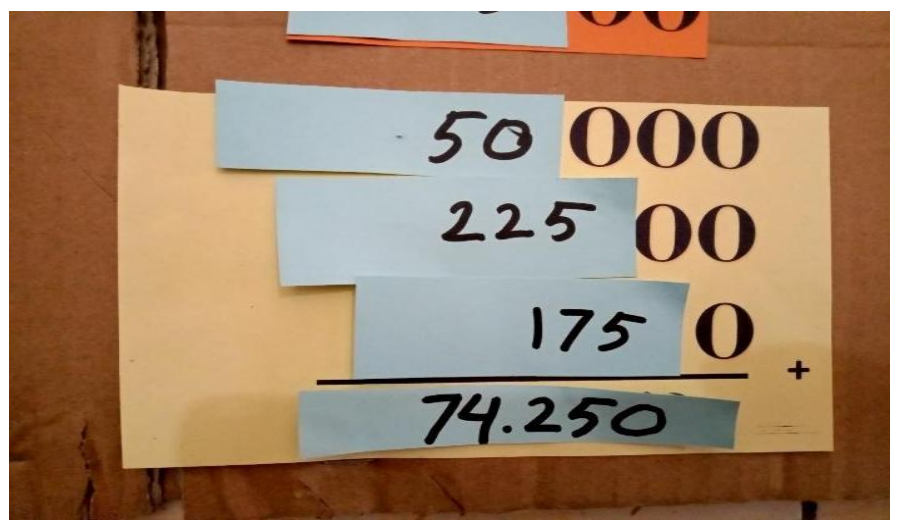

Gambar 4. Langkah Penjumlah dalam Media Wheelsmatik 
Contoh soal dalam percobaan 2, menentukan zakat dari Rp9.280.000.00.

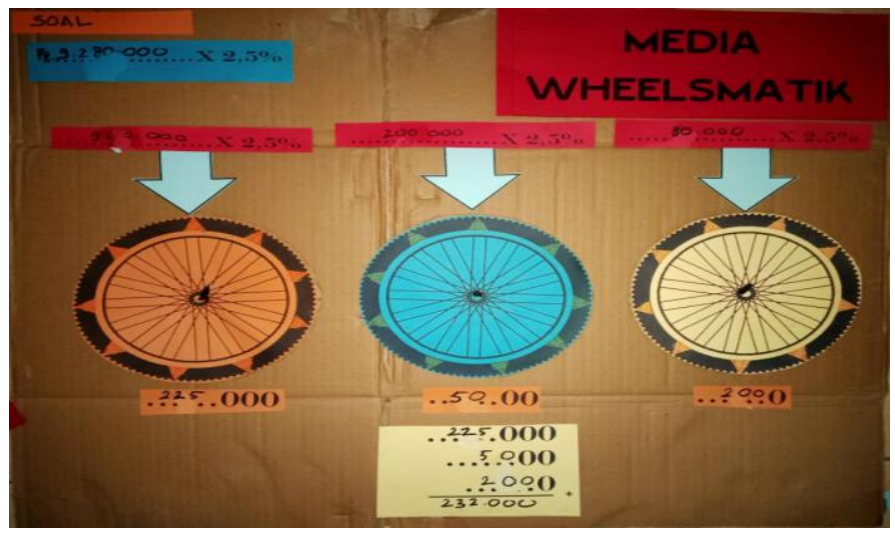

Gambar 5. Ilustrasi Penggunaan Media Wheelsmatik

Langkah penyelesaian soal percobaan pertama menentukan zakat dari Rp. 9.280,000.00 sebagai berikut. (1) Menulis soal dibagian atas kiri media Wheelsmatik; (2) Nominal 9.280.000 dibagi menjadi 3 bagian yaitu ditulis di atas roda pertama nominal $9.000 .000 \times 2.5 \%$, di atas roda kedua ditulis nominal $200.000 \times 2.5 \%$, dan di atas roda ketiga ditulis nominal 80,000 x 2.5\%. dan (3) Hasil perkalian di roda pertama 9,000,000 × 2.5\% maka di roda diputar pada angka 225 disesuaikan panah di atas roda pertama, hasil perkalian di roda kedua $200.000 \times 2.5 \%$ maka diroda diputar pada angka 50 disesuaikan panah diatas roda kedua, dan hasil perkalian 80.000 × 2.5\% maka di roda ketiga pada angka 200 disesuaikan panah diatas roda ketiga; (4) Setelah didapat angka di masingmasing roda maka hasilnya ditulis di bagian bawah roda. Roda pertama menunjukkan angka 225, maka ditulis di bawah roda ditambah 000 hasilnya 225.000, roda kedua menunjukkan angka 50, maka ditulis dibawah roda ditambah 00 hasilnya 5.000, dan roda ketiga menunjukkan angka 200, maka ditulis di bawah roda ditambah 0 hasilnya 2.000 ; 5) Setelah mendapatkan hasil perkalian masingmasing roda, maka semua nilai dijumlahkan di bagian bawah media Wheelsmatik. hasil perkalian pada roda pertama $9.000 .000 \times 2.5 \%$ hasilnya 225.000 , hasil perkalian pada roda kedua $200.000 \times 2.5 \%$ hasilnya 5.000 , dan hasil perkalian roda ketiga $80,000 \times 2.5 \%$ hasilnya 2.000 . Hasil penjumlahan dari ketiga hasil tersebut adalah $225.000+5.000+2 ., 000$, maka hasilnya 232.000 . 

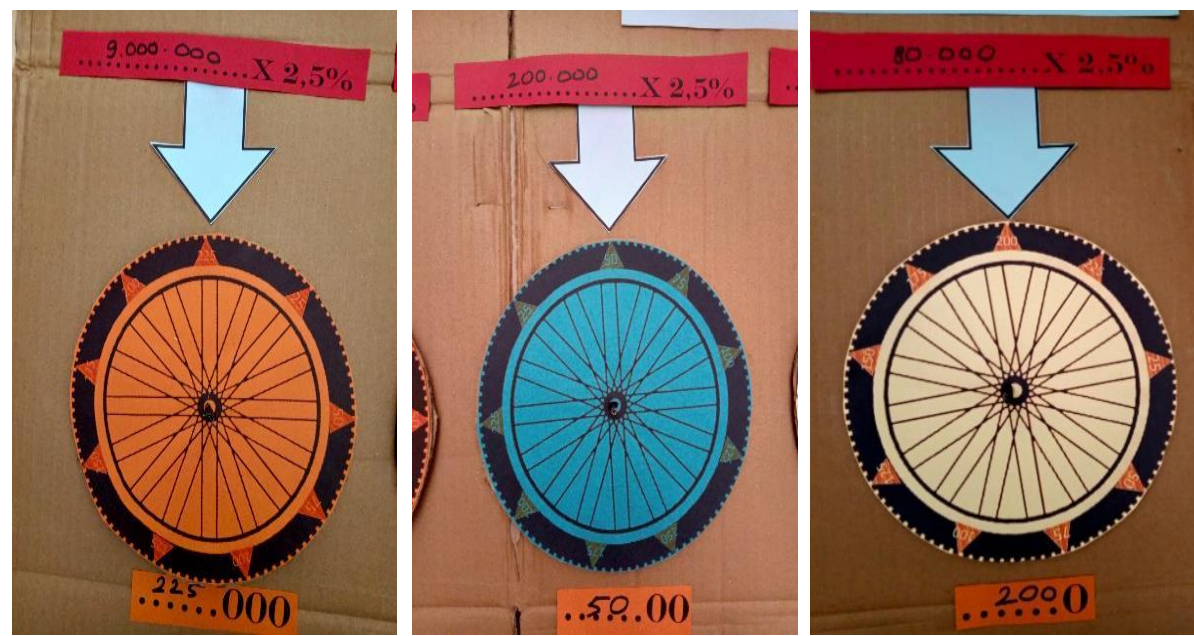

Gambar 6. Langkah Perkalian dengan Media Wheelsmatik

Setelah ketiga roda berhasil menunjukkan perkalian baik nominal jutaan, ratusan ribu dan puluhan ribu. Maka pada bagian bawah media Wheelsmatik terdapat penjumlahan dari hasil perkalian ketiga roda tersebut yaitu roda pertama 225.000, roda kedua 5.000 dan roda ketiga 2.000 maka hasilnya 232.000. Maka hasil zakat yang dikeluarkan dari harta Rp9.280000.00 x 2.5\% adalah Rp232.000.00. Dapat dilihat di media Wheelsmatik sebagai berikut.

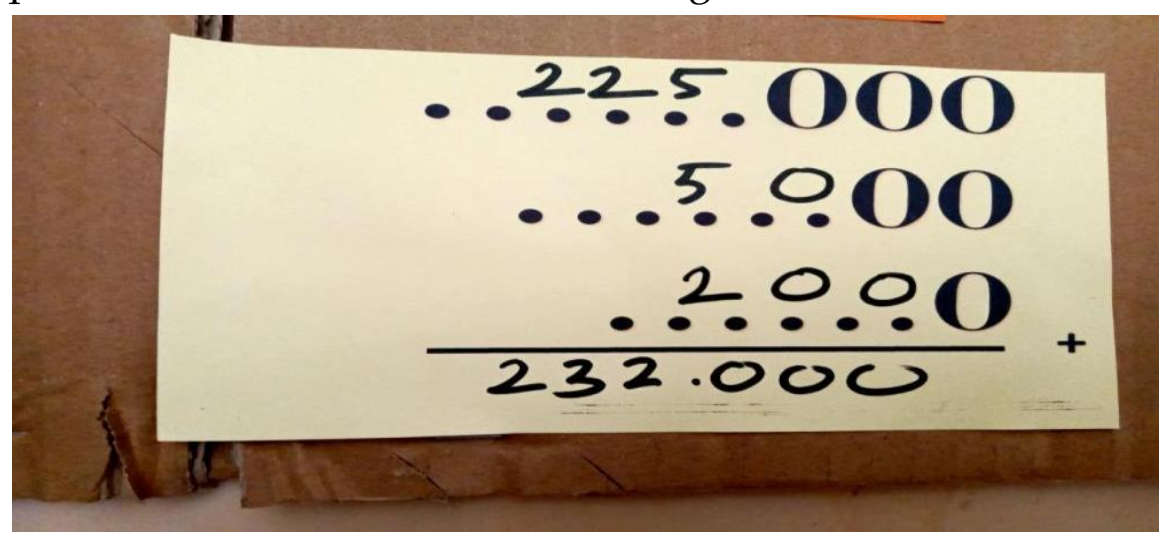

Gambar 7. Langkah Penjumlah dalam Media Wheelsmatik

Dari percobaan pertama dan percobaan kedua, maka dapat dilihat betapa mudahnya menyelesaikan permasalahan pembelajaran dalam 
menentukan zakat, walupun dengan nominal jutaan rupiah. Pembelajaran Pendidikan Agama Islam dan Budi Pekerti terutama dalam materi zakat terutama menentukan jumlah zakat seseorang akan mudah dipahami siswa dengan menggunakan media Wheelsmatik ini.

Hasil pembelajaran sebelum menggunakan media Wheelsmatik diperoleh rata-rata 75.38, terdapat 3 siswa yang mendapat skor 60 dan 3 siswa yang mendapat nilai skor 70, artinya masih belum memenuhi Kriteria Ketuntasan Minimal 75. Hal ini dapat disimpulkan bahwa pembelajaran sebelum menggunakan media Wheelsmatik diangggap belum berhasil. Setelah dilakukan refleksi dari hasil pembelajaran tersebut, penulis menggunakan media Wheelsmatik dalam pembelajaran yang sama. Pada percobaan pertama siswa diberikan soal menentukan zakat dengan nominal Rp2.970.000, maka didapat peningkatan hasil belajar siswa dengan mendapat nilai rata-rata 83.07, namun masih terdapat 3 siswa yang mendapat nilai 70, artinya masih di bawah nilai Kriteria Ketentuan Minimal 75. Pada percobaan kedua siswa masih kebingungan dalam menggunakan media Wheelsmatik sehingga masih terdapat 3 siswa belum tuntas Kriteria Ketentuan Minimal.

Melalui hasil refleksi hasil belajar pada percobaan pertama, maka penulis melakukan percobaan kedua dengan memberikan soal dengan nominal Rp9.280.000.00.

Peningkatan tersebut dapat ditafsirkan sebagai peningkatan pemahaman konsep matematis siswa dalam pembelajaran Pendidikan Agama Islam dan Budi Pekerti pada materi zakat. Hal ini dapat disimpulkan bahwa pembelajaran dengan menggunakan media Wheelsmatik mampu membuat pengalaman belajar siswa bertambah dan pembelajaran menjadi bermakna bagi siswa karena siswa belajar dengan media konkrit. Kesimpulan tersebut karena melihat peningkatan yang terlihat dari pemahaman siswa dalam menentukan jumlah zakat yang dikeluarkan seseorang dengan sangat mudah.

Analisis praktis hasil pengaplikasian inovasi pembelajaran dilaksanakan dengan membandingkan dan melihat perbedaan hasil belajar siswa pada materi zakat mata pelajaran Pendidikan Agama Islam dan Budi Pekertidan Budi Pekerti. Berikut merupakan hasil belajar siswa sebelum menggunakan 
media Wheelsmatik pada materi zakat dengan nilai Kriteria Ketentuan Minimal 75.

Tabel 2. Hasil Belajar sebelum Menggunakan Media Wheelsmatik

\begin{tabular}{|c|c|c|c|}
\hline No & Banyaknya siswa & Nilai yang diperoleh & Jumlah \\
\hline 1 & 3 & 60 & 180 \\
\hline 2 & 3 & 70 & 210 \\
\hline 3 & 5 & 80 & 400 \\
\hline 4 & 1 & 90 & 90 \\
\hline 5 & 1 & 100 & 100 \\
\hline \multicolumn{2}{|c|}{ Rata-rata } \\
\hline
\end{tabular}

Berikut ini merupakan hasil belajar siswa pada pembelajaran materi zakar dengan mengggunakan media Wheelsmatik dengan nilai KKM 75 pada soal ujicoba pertama

Tabel 3. Hasil Belajar setelah Menggunakan Media Wheelsmatik Ujicoba 1

\begin{tabular}{|c|c|c|c|}
\hline No & Banyaknya siswa & Nilai yang diperoleh & Jumlah \\
\hline 1 & 0 & 60 & 0 \\
\hline 2 & 3 & 70 & 210 \\
\hline 3 & 5 & 80 & 400 \\
\hline 4 & 3 & 90 & 270 \\
\hline 5 & 2 & 100 & 200 \\
\hline \multicolumn{2}{|c|}{ Rata-rata } \\
\hline
\end{tabular}

Setelah dilakukan percobaan pertama, penulis melakukan percobaan kedua dengan nominal yang lebih besar.

Berikut ini adalah hasil belajar siswa menggunakan media Wheelsmatik pada ujicoba 2 .

Tabel 4. hasil belajar setelah menggunakan media Wheelsmatik ujicoba 2

\begin{tabular}{|c|c|c|c|}
\hline No & Banyaknya siswa & Nilai yang diperoleh & Jumlah \\
\hline 1 & 0 & 60 & 0 \\
\hline 2 & 0 & 70 & 0 \\
\hline 3 & 8 & 80 & 60 \\
\hline 4 & 2 & 90 & 180 \\
\hline 5 & 3 & 100 & 300 \\
\hline \multicolumn{3}{|c|}{ Rata-rata } \\
\hline
\end{tabular}

Hasil belajar diatas jika dimasukan dalam perbandingan grafik, dapat dilihat terjadi peningkatan yang signifikan sebelum dan setelah digunakan media Wheelsmatik baik percobaan pertama dan kedua.

Adapun grafik yang menunjukkan perbandingan prosentase hasil belajar siswa dapat dilihat pada diagram berikut. 


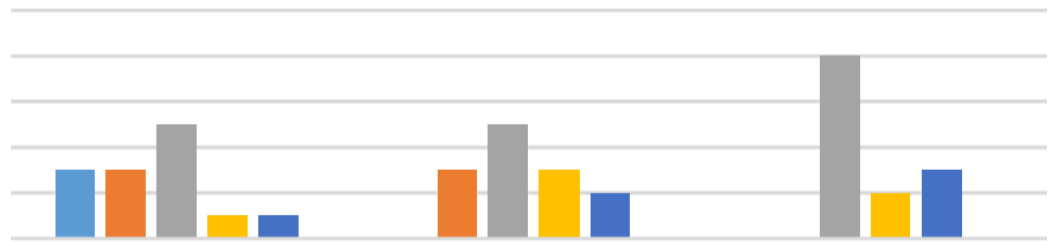

Gambar 8. Grafik Perbandingan Hasil Belajar

\section{Pembahasan}

Melihat hasil di atas, dapat disimpulkan bahwa penggunaan media Wheelsmatik pada pembelajaran Pendidikan Agama Islam dan Budi Pekerti materi zakat dapat dinyatakan berhasil. Media Wheelsmatik merupakan inovasi yang dilakukan penulis terinspirasi dari penggunaan media pembelajaran yang telah dimuat dalam Jurnal Didaktika Pendidikan Dasar pada Vol. 4, No. 1, Maret 2020 tentang media pengembangan media spedomatik pada pemahaman konsep nilai tempat di sekolah dasar yang ditulis oleh Setyawan. Dalam penulisan tersebut penulis mengembangkan media pembelajaran yang berupa 3 lingkaran seperti permainan spin. Media tersebut dapat memecahkan masalah penambahan dan pengurangan nilai tempat bilangan (Setyawan, 2020).

Media Wheelsmatik digunakan untuk memudahkan siswa memahami konsep matematis dalam mata pelajaran Pendidikan Agama Islam dan Budi Pekerti terutama materi zakat, karena dalam materi ini siswa harus mampu menentukan konsep matematis yang tepat. Oleh sebab itu, dilihat dari hasil penulisan di atas sebelum dan sesudah digunakan media Wheelsmatik terdapat peningkatan hasil belajar siswa, maka dapat dikatakan media Wheelsmatik berhasil meningkatkan pemahaman matematis siswa materi zakat. Media Wheelsmatik merupakan salah satu media manipulative, karena dengan media ini konsep penentuan zakat yang terbilang susah karena harus mencari $2.5 \%$ dari harta yang dimiliki, menjadi mudah dikerjakan dengan menggunakan media ini. 
Hal ini senada dengan pendapat Muhsetyo bahwa penggunaan media manipulatif mampu menyederhanakan konsep yang sulit kepada konsep yang kongkret. Siswa yang melakukan aktivitas manipulatif tergolong dalam tahapan enaktif, yaitu siswa sedang menggunakan pengetahuan motoriknya untuk memahami (Muhshetyo, 2007).

Pembelajaran menggunakan media Wheelsmatik merupakan salah satu pembelajaran kreatif karena guru dalam hal ini mengembangkan dan menggunakan media Wheelsmatik yang dapat memudahkan siswa dan menarik kreatifitas siswa. Hal ini senada dengan pendapat Winarno bahwa “pembelajaran kreatif merupakan pembelajaran yang menuntut guru mengembangkan kegiatan belajar yang beragam misalnya diskusi, tanya jawab, dan demonstrasi, serta menggunakan media pembelajaran yang bervariasi misalnya multi media, alat peraga yang sesuai dengan materi ajar yang akan membantu siswa dalam memahami suatu konsep yang akan diajarkan" (Winarno, 2002).

Pembelajaran Pendidikan Agama Islam dan Budi Pekerti dengan menggunakan media Wheelsmatik membuat siswa lebih tertarik dan merasa senang selama pembelajaran berlangsung. Walaupun menentukan zakat merupakan hal yang sulit, Penggunaan media Wheelsmatik membuat siswa antusias dan merasa mudah. Hal ini senada dengan pendapat Godon Dryden yang menyatakan bahwa "belajar lebih efektif jika dilaksanakan dalam suasana menyenangkan, sehingga pengetahuan yang kompleks sekalipun dapat diserap dengan mudah" (Dryden 2003).

Sejalan dengan pendapat di atas, Wardani mengatakan "pembelajaran kreatif adalah pembelajaran yang memberi kesempatan kepada siswa merancang, membuat, berkreasi, mengkomunikasikan gagasan, pendapat atau pikirannya melalui karya tertentu, secara tertulis maupun tidak tertulis" (Wardani 2004). Penggunaan media Wheelsmatik merupakan upaya menjadikan pembelajaran lebih kreatif lagi karena guru dan siswa dapat merancang, membuat, berpendapat, berkreasi, dan mengekplorasi pemikiranya dalam pembelajaran materi zakat.

Penyebarluasan atau diseminasi karya inovasi pembelajaran media Wheelsmatik dilakukan kepada rekan-rekan guru Pendidikan Agama Islam di 
Kelompok Kerja Guru Pendidikan Agama Islam Kecamatan Sambi. Melalui diskusi dengan rekan sejawat, media Wheelsmatik diharapkan dapat digandakan, minimal tiap guru Pendidikan Agama Islam I memiliki sendiri agar guru dan siswa se-kecamatan Sambi dapat lebih bebas menggunakan.

Ketika diseminasi dilakukan dalam lingkup Kelompok Kerja Guru Pendidikan Agama Islam se-kecamatan Sambi, Kabupaten Boyolali, penulis mendapatkan banyak sekali saran, salah satunya adalah pada bahan yang dipakai disarankan dengan bahan yang kuat dan awet, seperti kayu atau teriplek supaya tidak mudah rusak. Saran lain, agar media Wheelsmatik dapat dipatenkan dalam Hak Atas Kekayaan Intelektual (HAKI) supaya menjadi media pembelajaran yang dapat digunakan seluruh guru Pendidikan Agama Islam se-Indonesia khususnya di wilayah Boyolali.

\section{Penutup}

Penulisan tentang pengembangan media Wheelsmatik pada materi zakat pada mata pelajaran Pendidikan Agama Islam dan Budi Pekerti diharapkan dapat dijadikan solusi tentang permasalah dalam pembelajaran tentang menentukan nilai zakat seseorang. Setelah dilakukan penulisan maka penulis dapat menyimpulkan: Kesimpulan penelitian ini adalah (1) media Wheelsmatik berhasil digunakan untuk meningkatkan pemahaman matematis dalam permasalahan zakat; dan (2) Media Wheelsmatik terbukti sangat efektif diterapkan pada materi zakat di Sekolah Dasar Negeri 1 Jatisari, Sambi, Boyolali. Hal ini terlihat dari keaktifan siswa dan berpengalaman langsung belajar menyenangkan saat menggunakan media Wheelsmatik.

Saran yang dapat penulis sampaikan adalah (1) media Wheelsmatik baru diterapkan dengan nilai harta 1 - 9 juta saja karena menggunakan 3 roda, maka perlu pengembangan lebih lanjut supaya bisa menyelesaikan penentuan zakat dengan harta lebih dari 10 - 100 juta, (2) Media Weelmatik memiliki fungsi dasar penumbuhan konsep kongkrit dalam menyelesaikan konsep perkalian. Hal ini perlu dikembangkan agar konsep matematis tidak hanya abstrak semata. 


\section{Ucapan Terimakasih}

Ucapan terima kasih saya sampaikan kepada Direktorat Pembinaan Guru Pendidikan Dasar, Dirjen Guru dan Tenaga Kependidikan, Kementerian Pendidikan dan Kebudayaan, Dinas Pendidikan dan Kebudayaan kabupaten.

\section{Daftar Referensi}

Achmadi. 2005. Ideologi Pendidikan Islam, Paradigma Humanisme Teosentris. Yogyakarta.

Ahmad tafsir. 1992. Ilmu Pendidikan Dalam Perspektif Islam. Bandung: PT. Remaja Rosdakarya.

Baggon, ET. AL. 2010. Error Patterns in Computation. Englewood Cliffs: Nj: Prentice Hall.

Dryden, Godon \& Jeanette Vos. 2003. The Learning Revolution. Bandung: Keifa.

Dwi Setyawan, Dedy. 2020. "Pengembangan Media Spedomatik Pada Pemahaman Konsep Nilai Tempat Di Sekolah Dasar." Jurnal Didaktika Pendidikan Dasar 4 (1):1-18. https://doi.org/10.26811/didaktika.v4i1.120.

Fonna, M., \& Mursalin, M. (2018). Role of Self-Efficacy Toward Students' Achievement in Mathematical Multiple Representation Ability (MMRA). Jurnal Ilmiah Peuradeun, 6(1), 31-40. doi:10.26811/peuradeun.v6i1.174

Muhshetyo, Dkk. 2007. Pembelajaran Matematika di SD. Jakarta: Universitas Terbuka.

Sanjaya, W. 2008. Strategi Pembelajaran Berorientasi Standar Proses Pendidikan. Jakarta: Kencana Predana Media Group.

Sukiman. 2012. Pengembangan Media Pembelajaran. Yogyakarta: Pedagogia.

Thiagarajan, S., Semmel, S.D. \& Semmel, M. L. 1974. Instructional Development for Training Teacher of Expectional Children: A Sourcebook. Indiana University.

Vitoria, L., \& Monawati, M. (2016). Improving Students' Problem Solving Skill in Mathematics Through Writing. Jurnal Ilmiah Peuradeun, 4(2), 231-238. doi:10.26811/peuradeun.v4i2.100

Wardani, Sri. 2004. Strategi-Pendekatan-Metode Pembelajaran Matematika Di Sekolah Dasar. Yogyakarta: PPPTK Matematika.

Winarno. 2002. Merancang Pembelajaran Matematika Berorientasi Pada PAKEM Dan Pembekalan Kecakapan Hidup. Yogyakarta: PPPTK Matematika. 
